\title{
Economic efficiency of conversion of classical fish farm in organic by use of wastes fish in Green Houses
}

\section{CATALIN COSTIN ONIGA ${ }^{1}$, DORINA MOCUTA ${ }^{2}$, STELICA CRISTEA ${ }^{3}$, ŞTEFANA JURCOANE ${ }^{1,4}$}

${ }^{1}$ University of Agronomic Sciences and Veterinary Medicine of Bucharest, Faculty of Biotechnology, 59 Mărăşti Blvd, Bucharest, Romania

${ }^{2}$ University of Agronomic Sciences and Veterinary Medicine of Bucharest, Faculty of Management, Economic Engineering in Agriculture and Rural Development, 59 Mărăşti Blvd, Bucharest, Romania ${ }^{3}$ University of Agronomic Sciences and Veterinary Medicine of Bucharest, Faculty of Agriculture, 59 Mărăşti Blvd, Bucharest, Romania

${ }^{4}$ Academy of Romanian Scientists, 3 Ilfov Street, Bucharest, Romania

\begin{abstract}
The scientific approach of the following paper refers to an integrated system between aquaculture and hydroponics called aquaponics, a sustainable technology of producing food and diminishing waste. Implementing an aquaponic system would be a response to the drastic global changes such as climate imbalance, soil degradation, water shortage, population growth and so on. Building a system of this kind should be highly related to its economic perspective. There is scarce research regarding the economic expectation and too irrelevant to conclude a point of view. A good example of a similar practice has been applied to Cornell University (US-Professor Michael Timmons). Engineering input and perspective on responsible aquaculture development with an emphasis on business management and formation were provided to us. Considering this, we find it very challenging and we are determined to test the application of an aquaponic system in the hospitality business sector. The advantages of this application are: fresh fish and quality greens, small production surface, controlled environment, sufficient income to sustain a family and tourism development in Danube regions. The investment, overall performance and economic return are management dependent. A real risk evaluation process could improve the system added value.
\end{abstract}

Keywords Aquaponics, hydroponics, fish farm, management, economic profitability.

To cite this article: ONIGA CC, MOCUTA D, CRISTEA S, JURCOANE Ș. Economic efficiency of conversion of classical fish farm in organic by use of wastes fish in Green Houses. Rom Biotechnol Lett. 2020; 25(6): 2174-2179. DOI: 10.25083/rbl/25.6/2174.2179

*Corresponding author: CATALIN COSTIN ONIGA, University of Agronomic Sciences and Veterinary Medicine of Bucharest, Faculty of Biotechnology, 59 Mărăşti Blvd, Bucharest, Romania E-mail: oniga.catalin@yahoo.com 


\section{Introduction}

Fisheries and aquaculture make crucial contributions to the world's wellbeing and prosperity. In the last five decades, world fish food supply has outpaced global population growth, and today fish constitutes an important source of nutritious food and animal protein for much of the world's population. A rise in aquaculture productivity also increases food and nutrition security by making fish available and affordable for the growing population that depends on fish and fish products (FAO, 2016).

Aquaponics is the integration of aquaculture and hydroponics. There is expanding interest in aquaponics as a form of aquaculture that can be used to produce food closer to urban centres. Commercial aquaponics uses methods and equipment from both the hydroponics and aquaculture industries (LOVE et al, 2015). Aquaponic system is actually the combination of fish and plant production in a symbiotic environment. Animals such as snails, fish, crayfish or prawns grown in tanks can be combined with cultivating plants in the same solution of water and nutrients. Throughout the growing process, you will need to control several factors, such as lighting, water quality, air circulation, and more. Aquaponics has a huge potential as a sustainable solution since it demonstrates promising results for urban and rural food development (EL-ESSAWY et al, 2019). In addition, the European Union is providing funding for agriculture, aquaculture, tourism and rural development encouraging entrepreneurs and start-up opportunities. Although this presents a huge opportunity especially for developing countries like Romania it still requires further studies and researches to fully overcome foreseen challenges. We strongly believe tha aquaponics can complement the sustainable development of tourism in rural areas such as The Danube Gorges located in "The Iron Gates Natural Park" of Romania. The construction of the "Iron Gates" hydroelectric power plant together with chaotic tourism development in this region has represented a threat to the Danube's fish population. Endangered species such as sturgeons have completely extinct from the Iron Gates Natural Park. This study discusses the possibility of implementing aquaponics as an alternative to commercial fishing in this Danube region through a comparison between aquaponics products and conventional fish farms products.

\section{Romania overview}

The country's land resources and availability of inland waters provide perfect conditions for the development of aquaculture.

In Romania, the structure of aquaculture population is dominated by cyprinids, representing almost 85 percent of the total production, followed by trout, perch, pike, catfish and fresh water sturgeons (15 percent). The farming system traditionally used in Romanian aquaculture is extensive or semi-intensive, mainly based on cyprinid policulture rearing in ponds.

There are over 500 fish farms, covering a total surface of approximately 80,000 ha, plus a 400 vessel fleet (mainly for inland waters). Nevertheless, local producers are small sized, with the internal fish production covering less than 20 percent of the total fish consumption in Romania.

In 2010, aquaculture production was 8,781 tonnes, being dominated by common carp (Cyprinus carpio $2,888.10$ tonnes) and by the three carp species (silver carp, bighead carp, grass carp overcoming carp production 3,119.67 tonnes). The graph below shows total aquaculture production in according to FAO (2016) statistics.

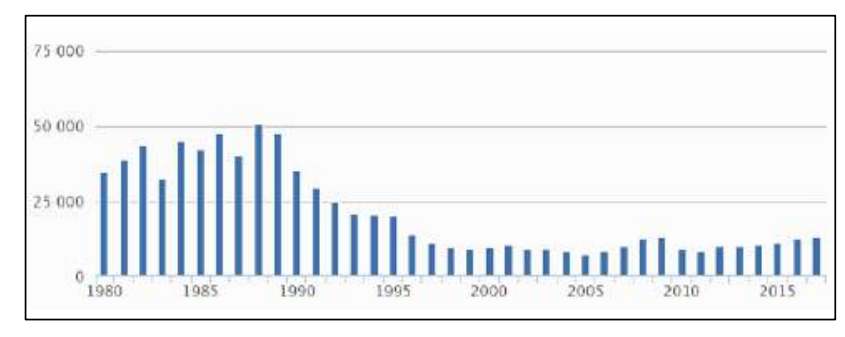

Figure 1. Total aquaculture production for Romania (tonnes).

The current domestic fisheries production cannot cover the internal market demand, which is continuously increasing. This is compensated by imports that represent an important amount of the fish market in Romania 80,161 tonnes in 2005, while exports were only 816 tonnes.

The statistic interferences shown that people aged between $30-55$ years $(82.60 \%)$ prefer live fish, young people, younger than 30 years $(60.97 \%)$ prefer fresh fish and/or seafood (43.90\%). The most of the respondents $(60.00 \%)$ prefer to buy from specialized stores (fisheries) and $27.50 \%$ direct from the producer (NICOLAE et al, 2016).

Low productivity and poor quality of products are mainly influenced by: limited access to credit, insufficient and inefficient use of existing resources, obsolete infrastructures and equipment, energy intensive technologies, insufficient training of the staff, lack of or inefficient management and marketing knowledge (most domestic companies still base their strategies on cost reduction and not on productivity increase).

Tourism is one of the most important sectors of the economy of a country, but any event with negative connotations such as the appearance of epidemics, terrorist attacks, economic or social instability influences the activity in this sector (MARCUTA et al, 2020).

In this context, the priorities of the strategy shall be established around the following three development milestones:

- Ensure the sustainability of the current aquaculture sector in Romania.

- Develop the aquaculture products market.

- Enhance the administrative capacity of the Romanian fisheries administration.

Our mission is to develop a system that can produce fish and leafy vegetables. The products will be sold to the restaurants and local supermarkets in the "Iron Gates" area. 


\section{Aquaponics}

\section{Basic concept}

Aquaponics is a method that utilizes unconventional approach of fish and crop production combining aquaculture with hydroponics. The plants filter waste products that are harmful to the fish from the system by utilizing them as a nutrient source (RAKOCY et al, 2004).

Researchers and growers aim to turn the aquaponics into a real sustainable food production model, because the waste that gets out of one biological system (fish) serves as nutrients for the other biological system (plants). The combination of fish and plants' results raises several products. Re-using water after mechanical and biological filtration and recirculation provides local healthy food that can support the local economy (DIVER, 2006).

The culture water is evacuated from the fish tank which contains the fish metabolic waste, passing first through a mechanical filter which retains solid waste and after that through a biofilter which oxidizes ammonia to nitrate, all of it in a continuously recirculating unit. Travelling then through plant grow beds, where the plants assimilate the nutrients, the purified water returns finally to the fish tank (Figure 2).

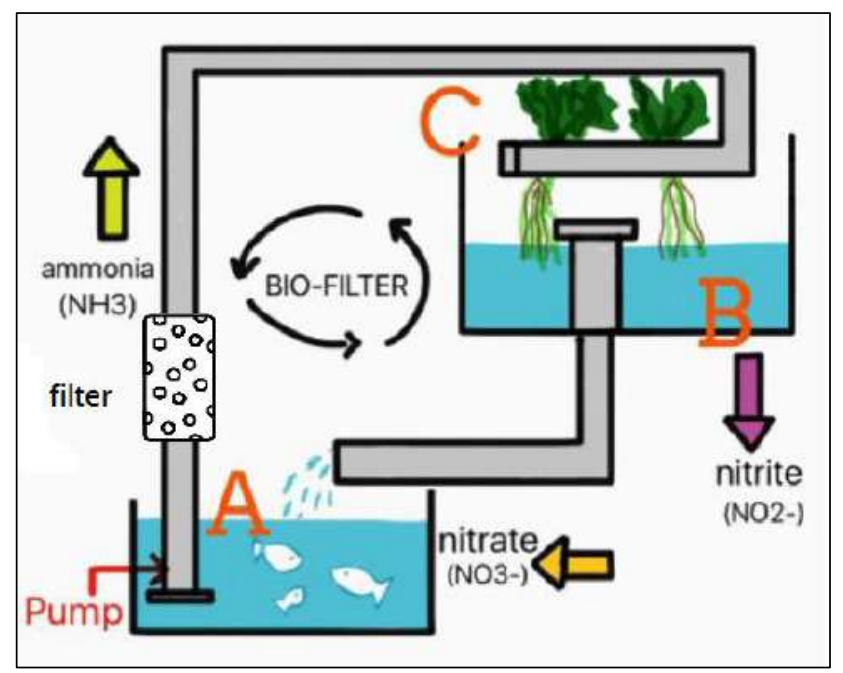

Figure 2. Aquaponics' cycle (Adapted from FAO, 2016)

Bacteria can convert fish waste into accessible nutrients for plants with the help of the habitat offered by the biofilter. Dissolved in the water, these nutrients can be then absorbed by the plants. Cleaning the water and preventing the water from becoming toxic due to the harmful forms of nitrogen (ammonia and nitrite), the process of nutrient removal allows the plants, fish and bacteria to prosper symbiotically.

If the system is properly balanced all the organisms work together to create a healthy environment for each other (SOMERVILLE et al, 2014).

Plant selection in aquaponics relates to fish density in fish tanks and nutrient concentration. Lettuce, herbs, basil, and watercress are considered to have low nutritional requirements, while yielding fruit like tomatoes and peppers need higher nutritional requirements. On the other hand, several fish species are adapted to aquaponics. Nile tilapia is one of species which live in warm water and grows well in aquaponics' fish tank culture. It can also adapt quickly to different conditions of water such as temperature, $\mathrm{pH}$, oxygen, and other solids dissolved in water (FAO, 2016). Yet, we are not focused on Nile tilapia but on Sander lucioperca (Figure 3).

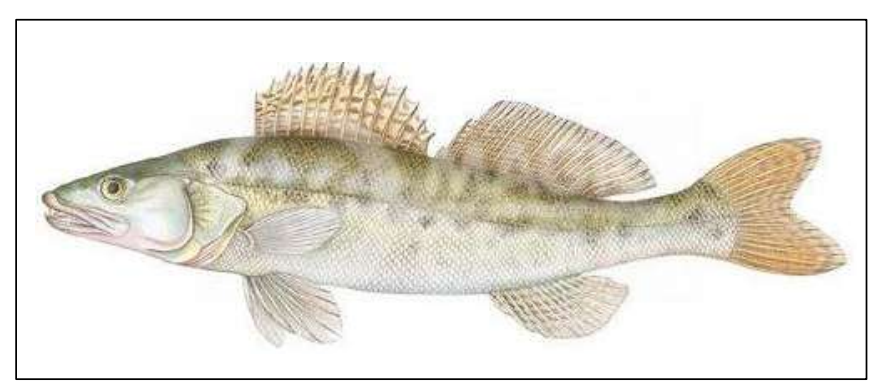

Figure 3. Sander lucioperca

\section{Pikeperch}

It represents the fish we are interested in growing in the aquaponic system together with leafy vegetables valuable on the local market.

Pikeperch (Sander lucioperca) is a valuable fish species identified as an important candidate for aquaculture in Recirculating Aquaculture Systems (RAS) in all Europe (PHILIPSEN, 2008; FAO, 2016).

So far, significant scientific work was focused particularly on pikeperch feeding this influencing directly their growth performance. At the moment, the RAS rearing technology is not entirely optimized, several technological aspects remaining partly studied (ÖZYURT et al, 2012; ZAKĘŚ et al, 2003; NYINAWAMWIZA et al, 2005; RONYAI and CSENGERI, 2008; WANG et al, 2009; KOWALSKA et al, 2010).

Pike perch, native to eastern Europe inhabits rivers and feeds regularly on fishes also insects and crustaceans. Attains a maximum length of $130 \mathrm{~cm}$ and weight of 12-18 kg; usually 30-70 cm (FAO, 2016).

\section{Materials and Methods}

A pilot-scale quaponic system has been set up to test the economic efficiency of producing fish and leafy vegetables for a restaurant in the "Iron Gates" natural park area. The objective was to test the possibility of supplying the restaurant with fresh products straight from a sustainable source. To such a degree, the supply cost of fresh fish would drop significantly and the profit of the business would increase. Our purpose was to produce at least $200 \mathrm{~kg}$ of fish/year. Complementary produced vegetables were sold to other restaurants to help diminish the annual running costs of the aquaponic system.

The aquaponic system model is similar to the one described by Asciuto et al. (2019). The hydroponics system occupies a total area of around $30 \mathrm{~m}^{2}$, and this also includes the handling areas. It comprises 12 wood cultivation boxes, which are encased in polyvinyl chloride 
(PVC) material. The media bed technique (MBT) is used (Figure 2), where tanks are filled with a porous substrate of an inert mix of expanded clay and lava rock; the latter acts as a support for the rooting system of the plants and as a mechanical and biofilter (SOMERVILLE et al, 2014).

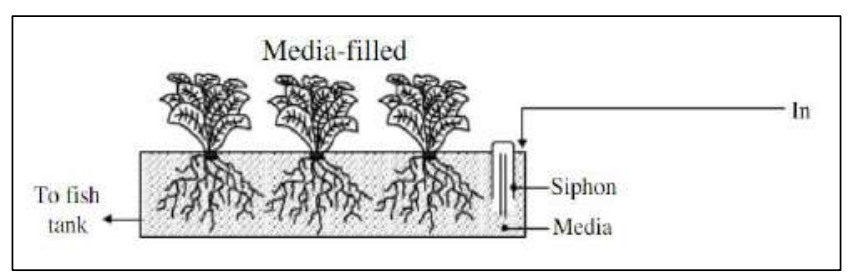

Figure 2. Media bed aquaponic system
Also comprising 3 tanks constructed from high density polyethylene (HDPE), encased in a polyvinyl chloride (PVC) material with a capacity of 1000 litres each, the aquaponic plant has a $15 \mathrm{~m}^{2}$ cultivable area of and a $3 \mathrm{~m}^{3}$ capacity for fish rearing. The aquaponic system is equipped with 3 sump pumps, which are continuously operating to moisten the plant beds. Water flows through the entire system via low density polyethylene (LDPE) pipes. Two siphons regulate excess water excess in every grow bed, draining it into the fish tank (ASCIUTO et al, 2019).

Financial investment for building the system was provided by the restaurant owner and is presented in (Table 1).

Table 1. Investment cost (€)

\begin{tabular}{|c|c|c|c|}
\hline Item & Quant. & Cost/unit & Total cost \\
\hline Grow bed & 12 & 28.00 & 336.00 \\
\hline Fish rearing tank $1000 \mathrm{lt}$ & 3 & 96,66 & 290.00 \\
\hline Grow beds structure support & 30 & 17.20 & 516.00 \\
\hline Galvanized edge for grow beds & 24 & 1.80 & 43.20 \\
\hline Corrugated pipe for cable protection $12 \mathrm{~m}$ & 3 & 3.5 & 10.50 \\
\hline Expanded clay $50 \mathrm{lt}$ & 20 & 3.75 & 75.00 \\
\hline Lava rock $1 \mathrm{~kg}$ & 24 & 1.10 & 26.40 \\
\hline Siphon & 24 & 15.30 & 367.20 \\
\hline Submersible water pump $400 \mathrm{~W}$ & 3 & 35.00 & 105.00 \\
\hline Irrigation pipes and fittings $60 \mathrm{~m}$ & 1 & 28.50 & 28,50 \\
\hline \multicolumn{3}{|l|}{ Total cost for facility components } & $1,797.80$ \\
\hline \multicolumn{3}{|l|}{ Set up } & 250.00 \\
\hline \multicolumn{3}{|l|}{ Total investment cost } & $2,047.80$ \\
\hline
\end{tabular}

Alongside investment costs there are annual running costs presented in Table 2. As we were using water from a well there were no costs involved. Depreciation was computed as $10 \%$ of the total cost for facility components. Maintenance means a man working $1 \mathrm{~h} /$ day - 4 days/week fish feeding and cleaning the tanks, with an average of $€ 2$.6/hour. Fish feed was marketed at $25 \mathrm{~kg} /$ pack at a cost of $€ 45$ and fingerlings were provided by a Romanian company.

Table 2. Annual running cost $(€)$

\begin{tabular}{|l|c|}
\hline Item & Value \\
\hline Depreciation & 179.78 \\
\hline Maintenance & 500.00 \\
\hline Energy & 187.00 \\
\hline Water & 0 \\
\hline Fish feed & 183.00 \\
\hline Seedling transplants & 92.00 \\
\hline Fingerlings & 35.62 \\
\hline Total running cost & $\mathbf{1 , 1 7 4 . 4 0}$ \\
\hline
\end{tabular}

\section{Results and Discussions}

The study outlined in this paper shows a total investment cost of $€ 2047$ for a pilot unit with a surface area of $15 \mathrm{~m}^{2}$ and 3 fish tank volume of $1 \mathrm{~m}^{3}$ each. Annual running costs, summarised in Table 2, amount to $€ 1,174$. Such results indicate that labour cost is the most preponderant item $(42 \%)$. In line with findings from other studies (QUAGRAINIe et al, 2017; BOSMA et al, 2017; TOKUNAGA et al, 2015; RUPASINGHE and KENNEDY, 2010), labor is the main cost item (approximately $50 \%$ of total operating costs).

In order to assess the financial feasibility of the pilot aquaponic unit, we had to analyse the production cost for one head of lettuce or one kilogram of fish so we can compare them with the selling price on the market. Table below presents the price evolution for one kilogram of fresh Pikeperch from the local market. Nowadays, the price is higher with $83 \%$ than it was 20 years ago when the restaurant business started.

Table 3. Pikeperch price evolution $(€ / \mathrm{kg})$

\begin{tabular}{|c|c|c|c|c|c|c|}
\hline Year & 2000 & 2005 & 2010 & 2015 & 2020 & $\begin{array}{c}2020 / \\
2000 \\
(\%)\end{array}$ \\
\hline $\begin{array}{c}\text { Pikeperch } \\
\text { euro/kg }\end{array}$ & 2.40 & 2.80 & 3.20 & 3.70 & 4.40 & 83.33 \\
\hline
\end{tabular}

After one year of production we concluded 6075 head of lettuce harvested in 9 cycles and $210 \mathrm{~kg}$ of fish grown in 2 cycles (Table 4 ). At each harvesting cycle 675 heads of lettuce and $105 \mathrm{~kg}$ of fish we harvested. The farming density for fish farming was 120 fish per m3; the fish completed their cycle in 6 months, when they achieved a unit weight of at least $300 \mathrm{~g}$, and an annual production of $210 \mathrm{~kg}$ of fish (600 fish in 2 production cycles) was obtained (ASCIUTO et al, 2019). 
The fish harvest was set to 300 grams so it could sell as a whole cooked fish to the customer in the restaurant. As reported by Bosma et al. (2017), the production of low-weight, live fish is profitable because it reduces the costs of fish feeding (thanks to a shorter feeding period) and fingerling purchase (due to lower mortality).

Table 4. Production cost of lettuce and fish

\begin{tabular}{|c|c|c|}
\hline Item & Vegetables & Fish \\
\hline Unit production/cycle & $45 \mathrm{head} / \mathrm{m}^{2}$ & $35 \mathrm{~kg} / \mathrm{m}^{3}$ \\
\hline No. annual harvesting cycles & 9 & 2 \\
\hline Surface area and/or volume & $15 \mathrm{~m}^{2}$ & $3 \mathrm{~m}^{3}$ \\
\hline Annual production & 6075 & 210 \\
\hline Annual cost & 1174.40 & 1174.40 \\
\hline Production cost & $€ 0,19 / \mathrm{head}$ & $€ 5,59 / \mathrm{kg}$ \\
\hline
\end{tabular}

At an annual running cost of $€ 1174$ we determined a production cost of $€ 5.59 / \mathrm{kg}$ for fish or $€ 0.19 / \mathrm{head}$ of lettuce. The conclusion is the following:

- At a production cost of $0,19 € /$ head of salad we grow $210 \mathrm{~kg}$ of fish or;

- At a production cost of $€ 5.59 / \mathrm{kg}$ of fresh fish we can produce approximately 6000 heads of lettuce.

Although our production cost for fish is higher than the market price we can focus on the lettuce production which can provide us income. Market selling price for regular lettuce is around $€ 0.40$ per unit. Bearing in mind our lettuces' freshness and pesticide free nature the selling price can slightly increase.

We assumed that fish production was intended for the restaurant and lettuce was worth commercialising to other units. So, at a simple computation from selling lettuce we can recover the initial sum invested in building the aqaponic system.

6000 heads of lettuce $\mathrm{x} € 0.40$ per unit $=€ 2400$.

\section{Conclusions}

Economic feasibility is proven by sustainably growing fish in order to produce and sell high quality lettuce even at low price.

The marketing quality of the lettuce is appreciated mainly considering the plant mass according to the quality standards and considering the percentage of nitrates and nitrites (DRĂGHICI et al, 2016).

In order to prove the financial feasibility of the system we had to come up with a cost lower than $4.40 € / \mathrm{kg}$ of fresh fish. From first perspective we have failed because we didn't consider the revenue generated from selling the lettuce. Remember, aquaponics is a symbiotic system, we feed fish in order to grow vegetables.

There are no concerns regarding the integration between fish and plant that could cause food safety problems. The results answer the research questions as aquaponics can be considered a strategy to conventional agriculture in Egypt today, and can be a strong alternative to conventional agriculture in the future. On the short term, aquaponics has one major drawback which is the high costs compared with those of conventional agriculture. However, on the long term, it could save the huge amounts of water wasted by conventional agriculture and land reclamation up to $85 \%$ (ALSHROUF, 2017).

From an environmental point of view, an aquaponic system prevents the leakage of aquaculture effluent, thus lowering environmental emissions and significantly reducing water consumption (TIMMONS and EBELING, 2007; VERDEGEM, 2013).

In conclusion, it can be stated that aquaponic systems can be a source of cash-flow if certain plant species, culture densities an aquaponic techniques are applied (PETREA et al, 2016).

\section{References}

1. ADAMS R.S., HUTCHINSON L.J., ISHLER V.A. (2009). Trouble-shooting problems with low milk production. Dairy and Animal Science, 4(1), 98-16.

2. ALSHROUF A. (2017). Hydroponics, aeroponic and aquaponic as compared with conventional farming. Am Sci Res J Eng Technol Sci (ASRJETS) 27:247-255

3. ASCIUTO A., SCHIMMENTI E., COTTONE C., \& BORSELLINO V. (2019). A financial feasibility study of an aquaponic system in a Mediterranean urban context. Urban Forestry and Urban Greening, 38 (July 2018), 397-402.

4. BOSMA R.H., LACAMBRA L., LANDSTRA Y., PERINI C., POULIE J., SCHWANER M.J., YIN Y. (2017). The financial feasibility of producing fish and vegetables through aquaponics. Aquac. Eng. 78, 146-154.

5. DIVER S. (2006). Aquaponics-integration of hydroponics with aquaculture. Attra.

6. DRĂGHICI E.M., DOBRIN E., JERCA I.O., BĂRBULESCU I.M., JURCOANE S. \& LAGUNOVSCHI-LUCHIAN V. (2016). Organic fertilizer effect on Lettuce (Lactuca sativa L.) cultivated in nutrient film technology. Romanian Biotechnological Letters, 21(5), 11905-11913.

7. FAO (2016). The State of World Fisheries and Aquaculture 2016: Contributing to Food Security and Nutrition for All. FAO, Rome, Italy.

8. KOWALSKA A., ZAKĘŚ Z., JANKOWSKA B., SIWICKI A. (2010). Impact of diets with vegetable oils on the growth, histological structure of internal organs, biochemical blood parameters, and proximate composition of pikeperch Sander lucioperca (L.). Aquaculture.

9. LOVE D.C., FRY J.P., LI X., HILL E.S., GENELLO L., SEMMENS K., THOMPSON R.E. (2015). Commercial aquaponics production and profitability: findings from an international survey. Aquaculture 435, 67-74.

10. MARCUTA L., DOROBANTU D.M., POPESCU A., TINDECHE C., MARCUTA A. (2020) The Influence Of Epidemics On Tourism Under The Conditions Of 
Globalization. Agrolife Scientific Journal, volume 9, number 1, ISSN 2285-5718, 214-220.

11. NICOLAE C.G., IȘFAN N., BAHACIU G.V., MARIN M.P., MOGA L.M. (2016). Case Study In Traceability And Consumer's Choices On Fish And Fishery Products. Agrolife Scientific Journal, Volume 5, Number 2, Issn 2285-5718, 103-107.

12. NYINA-WAMWIZA L., XU X., BLANCHARD G., KESTEMONT P. (2005). Effect of dietary protein, lipid and carbohydrate ratio on growth, feed efficiency and body composition of pikeperch Sander lucioperca fingerlings. Aquaculture Research, 36: 486-492.

13. ÖZYURT C.E., MAVRUK S., KIYAĞA V.B. (2012). Effects of Predator Size and Gonad Maturation on Food Preference and Feeding Intensity of Sander lucioperca (Linnaeus, 1758). Turkish Journal of Fisheries and Aquatic Sciences, 12: 315-322. doi: 10.4194/13032712-v12_2_17

14. PETREA S.M., COADĂ M.T., CRISTEA V., DEDIU L., CRISTEA D., RAHOVEANU A.T., ZUGRAVU A.G., RAHOVEANU M.M.T., \& MOCUTA D.N. (2016). A Comparative Cost - Effectiveness Analysis in Different Tested Aquaponic Systems. Agriculture and Agricultural Science Procedia, 10, 555-565. https://doi.org/10.1016/j.aaspro.2016.09.034

15. PHILIPSEN A. (2008). Excellence fish: production of pikeperch in recirculating system. In: Fontaine, P. Kestemont, P. Teletchea, F. Wang N. (Eds) Percid fish culture, from research to production. p. 67. Presses Universitaires de Namur, Namur, Belgium.

16. QUAGRAINIE K.K., VALLADÃO FLORES R.M., KIM H.J., MCCLAIN V. (2017). Economic analysis of aquaponics and hydroponics production in the U.S. Midwest. J. Appl. Aquac. 30 (1), 1-14.

17. RAKOCY J.E., BAILEY D.S., SHULTZ R.C., THOMAN E.S., 2004. Update on Tilapia and vegetable production in the UVI aquaponic system, New Dimensions onfarmed Tilapia: proceedings of the sixth international symposium on Tilapia inaquaculture. Held September, 12-16.

18. RONYAI A., CSENGERI I. (2008). Effect of feeding regime and temperature on growing results of pikeperch (Sander lucioperca L). Aquaculture Research, 39 2008: 820-827. doi: 10.1111/j.1365-2109.2008. 01935.X

19. RUPASINGHE J.W., KENNEDY J.O. (2010). Economic benefits of integrating a hydroponiclettuce system into a barramundi fish production system. Aquaculture Economic Management 14, 81-96.

20. SOMERVILLE C., COHEN M., PANTANELLA E., STANKUS A., LOVATELLI A. (2014). Small-scale aquaponic food production: integrated fish and plant farming. FAO Fisheries and Aquaculture Technical Paper, No. 589. FAO, Rome, pp. 262.

21. TIMMONS M.B., EBELING J.M. (2007). Recirculating Aquaculture. Cayuga Aqua Ventures, 126 Sunset Drive Ithaca, NY, USA.

22. TOKUNAGA K., TAMARU C., AKO H., LEUNG P. (2015). Economics of small-scale commercial aquaponics in Hawai. J. World Aquacult. Soc. 46 (1), 20-32.

23. WANG N., XU X., KESTEMONT P. (2009). Effect of temperature and feeding frequency on growth performance, feed efficiency and body composition of pikeperch juveniles (Sander lucioperca). Aquaculture, 289: 70-73. doi: 10.1016/j.aquaculture.2009.01.002

24. ZAKĘŚ Z., SZKUDLAREK M., WOZNIAK M., DEMSKA-ZAKĘŚS K., CZERNIAK S. (2003). Effects of feeding regimes on growth, within-group weight variability, and chemical composition of the juvenile zander, Sander lucioperca (L.) body. EJPAU, Poland 6 (2003). 